\title{
An Analysis of Student Difficulties in Mathematics Learning in terms of Student Mathematical Connection Ability on Pythagoras Theorem
}

\author{
${ }^{1 *}$ Viona Aida Sholeha, ${ }^{1}$ Risnawati, ${ }^{2}$ Habibullah \\ ${ }^{1}$ Mathematics Education, Universitas Islam Negeri Sultan Syarif Kasim Riau \\ ${ }^{2}$ Mathematics Education, Universitas Negeri Yogyakarta \\ *Corresponding Author e-mail: vionaaida43@gmail.com \\ Received: February 2021; Revised: April 2021; Published: June 2021
}

\begin{abstract}
This research aimed to describe student difficulties in mathematics learning in terms of student mathematical connection ability on Pythagoras theorem. This research was a qualitative descriptive research with case study design. The research subjects were 18 students on the IX grade, that further reduced into 5 students using purposive sampling technique. Triangulation data such as mathematical connection ability and difficulties of mathematic learning. Furthemore, tests and interview were used to collecting the data. The data were analyzed by Miles and Hubermen techniques including three stages: reduction, presentation, and conclusion/verification. The findings of this research showed that, each respondent has different difficulties at each mathematical connection ability level: (1) The subject (very high) mathematical connection ability level did not have problem with all indicators of difficulties in mathematics learning; (2) The subject (high) mathematical connection ability level had associations or visual-motor combination; (3) The subject (medium) mathematical connection ability level had associations or visual-motor combination and difficulties in recognizing and using symbols; (4) The subject (low) mathematical connection ability level had little spatial disruption, association or visual-motor combination, and little difficulties in recognizing and using symbols; (5) The subject (very low) mathematical connection ability level had spatial disruption, association or visual-motor combination, and difficulties in recognizing and using symbols.
\end{abstract}

Keywords: Student Difficulties; Mathematical Connection Ability; Pythagoras Theorem

How to Cite: Sholeha, V., Risnawati, R., \& Habibullah, H. (2021). An Analysis of Student Difficulties in Mathematics Learning in terms of Student Mathematical Connection Ability on Pythagoras Theorem. Prisma Sains: Jurnal Pengkajian Ilmu dan Pembelajaran Matematika dan IPA IKIP Mataram, 9(1), 12-19. doi:https://doi.org/10.33394/j-ps.v9i1.3510

\section{INTRODUCTION}

In era globalization, education is growing especially in the 21 st century which of course cannot be separated from the role of exact science which continues to develop, one of which is mathematics. Mathematics is the science of patterns and rules (Walle, 2007). Meanwhile, Sholihah \& Mahmudi (2015) stated that mathematics is another source of knowledge, because there are many sciences whose discovery and development depend on mathematics. In line with explanation above, Siagian (2016) also stated that one branch of science that has an important role in the development of science and technology is mathematics. This is because mathematics can be a tool in applying concepts in mathematics itself and in other fields of science. In addition, Manalu and Zanthy (2020) said that mathematics is an important knowledge for students to have for the creation of activities in everyday life. Therefore, mathematics is very useful for students as a basic science for the application of knowledge in other fields and for its application in everyday life.

But in reality, at this time mathematics is one of the subjects in schools that are known for their difficulties. As expressed by Rosyadi (2018) that mathematics is an abstract and deductive science. That is, in learning mathematics students need a high level of thinking to 
be able to understand abstract mathematical concepts and the ability to remember previously learned material because in mathematics there is a very clear and strong relationship between concepts. So that some students have difficulty learning mathematics. This is in accordance with the results of Siregar's research (2017) which found that as many as $45 \%$ of students perceive mathematics as quite difficult.

The difficulty in learning mathematics experienced by students is indicated by the existence of certain disturbances in achieving learning outcomes, so that in the end it can cause the level of student mathematics learning achievement to be below what it should be (Kumalasari \& Putri, 2013). This can be seen from the results of research conducted by TIMSS (Trens in International Mathematics and Science Study) which showed that the average score obtained by Indonesian students is 397 and is ranked 44th out of 49 participating countries (Mullis, Martin, Foy, \& Hooper, 2015). One of the assessment frameworks carried out by TIMSS is the content dimension consisting of numbers, geometry, and data presentation. One of the content dimensions that becomes the TIMSS assessment framework is geometry which shows that the scores obtained by Indonesian students are also based on students' mastery of the Pythagorean theorem material which is part of geometry (Prastyo, 2010).

In line with that, PISA (Program for International Student Assessment) stated that one of the materials discussed in geometry including the Pythagorean theorem is part of the content of mathematical literacy and for Indonesian results in 2018 regarding the mathematical abilities of Indonesian students announced by The Organization for Economic Cooperation and Development (OECD), namely Indonesia is ranked 72nd out of 79 OECD countries with a score of 379 which shows that Indonesia's math ability score is below the OECD average score for math ability which reaches a score of 489 (OECD, 2019).

The low achievement of learning mathematics shows that most students have difficulty learning mathematics, especially in the Pythagorean theorem. The difficulty of learning mathematics for students is related to the students' imperfect learning ability. To answer this problem, one of the five basic abilities that become the standard in mathematics learning according to NCTM (2020) is the ability to connect mathematically. In line with that, in the attachment to Permendikbud Number 22 of 2016 concerning Basic and Secondary Education Process Standards, it is explained that knowledge (cognitive) is obtained through the activity of "remembering, understanding, applying, analyzing, and evaluating". As for memory skills concepts in mathematics lessons and the skills to apply mathematics in other subjects, as well as in everyday life, are the ability of mathematical connections (Mulyani \& Muhtadi, 2019).

However, from the results of research conducted by Qabtiyah (2018) which explained that the results of the test results of the mathematical connection ability of class VIII MTs students in West Bandung Regency in solving the Pythagorean/phytagoras theorem are still low. In fact, students are required to have mathematical connection skills in learning mathematics, so that students can solve math problems well. In other words, the ability to connect mathematically is an important part that must be mastered by students at every level of education, so that students do not experience difficulty learning mathematics. This is reinforced by the results of research conducted by Sholekah, Anggreini, and Waluyo (2017) which can be concluded that the lower the level of mathematical connection skills of students, the more difficult these students are in solving math problems. In addition, the results of research conducted by Laili and Puspasari (2017) showed that the overall mathematical connection ability of students is still low, causing students to have difficulty learning mathematics with various types of learning difficulties.

Based on information obtained from mathematics teachers in class VIII and IX of SMPN 2 Batang Tuaka, most students have difficulty learning mathematics, especially in the material of the Pythagorean theorem. Students tend to have difficulty solving math problems, if the given math problems have a high level of difficulty. Thus, the author considers that it is necessary to conduct research on the difficulty of learning mathematics for students of SMPN 
2 Batang Tuaka on the Pythagorean theorem material in terms of the mathematical connection ability of students.

\section{METHOD}

This type of research is a qualitative descriptive research using case study design. According to Hartono (2019) qualitative research is a study that is intended to reveal symptoms holistically through data collection from natural contexts by utilizing researchers as core instruments. In addition, according to Sugiono (2016) qualitative research is a research method based on the philosophy of postpositivism used to research on natural object conditions, where researchers are as key instruments, data collection techniques are carried out in triangulation or combined, data analysis is inductive or qualitative, and qualitative research results emphasize meaning rather than generalization.

According to Trianto (2010) descriptive research is a research that seeks to describe a symptom, event, or situation that is being studied in detail and in depth. Data collection techniques used are data triangulation, using mathematical connection capability test instruments, math learning difficulty tests, and interview guidelines. All data is then analyzed using Miles and Huberman techniques, namely data reduction, data presentation, drawing conclusions and verification.

The mathematical connection test was given to 18 students of class IX at SMPN 2 Batang Tuaka to get the source of the data to be analyzed in this research. Furthermore, with the conversion of the student's mathematical connection ability scale, one of the students was selected as a representative which can be seen in Table 1 below.

Table 1. Conversion of Students' Mathematical Connection Ability Scala

\begin{tabular}{ccc}
\hline Interval & Total Score & Criteria \\
\hline$M+1,5 s<X$ & $71<X$ & Very High \\
$M+0,5 s<X \leq M+1,5 s$ & $49<X \leq 71$ & High \\
$M-0,5 s<X \leq M+0,5 s$ & $27<X \leq 49$ & Medium \\
$M-1,5 s<X \leq M-0,5 s$ & $5<X \leq 27$ & Low \\
$X \leq M-1,5 s$ & $X \leq 5$ & Very Low \\
\hline
\end{tabular}

Source: Azwar (2016)

\section{RESULTS AND DISCUSSION}

This study aims to describe and analyze the math learning difficulties of students of SMPN 2 Batang Tuaka Pythagoras theorem material reviewed from the level of mathematical connection ability of students. The following are the results of a mathematical connection ability test from 18 grade 1X students at SMPN 2 Batang Tuaka (Table 2).

Table 2. The Results of Students' Mathematical Connection Ability Test

\begin{tabular}{cccccc}
\hline Mathematical & Very High & High & Medium & Low & Very Low \\
\cline { 2 - 6 } $\begin{array}{c}\text { Connection } \\
\text { Ability }\end{array}$ & $71<X$ & $49<X \leq 71$ & $27<X \leq 49$ & $5<X \leq 27$ & $X \leq 5$ \\
\hline Frequency & 1 & 4 & 8 & 2 & 3 \\
\hline
\end{tabular}

From the data in table 2 above, one student from each category of mathematical connection ability level will be selected by asking the math subject teacher for consideration to ensure that the student chosen as the data source subject is able to communicate his/her idea. So obtained 5 research subjects that can be seen in Table 3 below. 
Table 3. The Research Subjects

\begin{tabular}{cccc}
\hline Subject Initials & Subject Code & Score & $\begin{array}{c}\text { Student Mathematical Connection } \\
\text { Ability Level Category }\end{array}$ \\
\hline WI & S-1 & 82 & Very High \\
SB & S-2 & 68 & High \\
KH & S-3 & 48 & Medium \\
FA & S-4 & 23 & Low \\
KL & S-5 & 5 & Very Low \\
\hline
\end{tabular}

To find out or diagnose the difficulties of learning mathematics experienced by students is reviewed from the level of mathematical connection ability, a math learning difficulty test consisting of 5 questions each representing 1 indicator of mathematical learning difficulties used in this study. For the first indicator, which is an indicator of disruption of room relationships, represented by question number 1 . The subject is said to meet the first indicator if it is difficult to determine the corresponding side of the wake shape on the question. The second indicator, the abnormality of perception or visual response, is represented by question number 2. The subject is said to meet the second indicator if it is difficult to determine the shape of the wake contained in the problem and difficulty determining the flat wake from waking on the question that can be used in the formula of Pythagoras theorem.

The third indicator, namely the association or visual-motor combination, is represented by question number 3 . The subject is said to meet the third indicator if it is difficult to use the formula in the problem. The fourth indicator, which is difficulty in recognizing and understanding symbols, is represented by question number 4 . The subject is said to meet the fourth indicator if it is difficult to recognize and understand the symbols used on the question. And the fifth indicator is difficulty in language and reading, represented by question number 5. The subject is said to meet the fifth indicator if it is difficult to understand the content of the given question. Based on the results of the math learning difficulty test and interviews with the research subjects, it can be said that each study subject has difficulty learning different mathematics according to the level of mathematical connection ability of the student, as follows: First, the subject with a very high level of mathematical connection ability (S-1) is able to complete the test question well. S-1 is capable of me.

Second, subjects with a high level of mathematical connection ability $(\mathrm{S}-4)$ have been able to identify problem information, understand problems, determine the corresponding side of the problem, distinguish various geometric shapes and be able to determine the type of triangle related to Pythagoras theorem material, be able to recognize and understand symbols, and be able to understand the content of the given story, and carry out the settlement correctly and not make miscalculations. However, $\mathrm{S}-4$ is not able to determine and use the formula to solve problem number 3 .

Third, subjects with moderate level of mathematical connection capability $(\mathrm{S}-3)$ have been able to identify problem information, understand problems, determine the corresponding side of the problem, distinguish various geometric shapes and be able to determine the type of triangle related to Pythagoras theorem material, as well as be able to understand the content of the given story, as well as carry out the settlement correctly and not make miscalculations. However, S-4 was unable to determine and use the formula to solve some of problem number 3 and was unable to recognize and understand the symbol to solve problem number 4.

Fourth, subjects with low level of mathematical connection capability (S-4) have been able to identify problem information, understand problems, distinguish various geometric shapes and be able to determine the types of triangles related to Pythagoras theorem material, be able to understand the content of the given story, and carry out solutions correctly and not make miscalculations. However, the S-4 is not able to determine the corresponding side of question number 1a, which is the command to find the diagonal length of the back side of the $\mathrm{ABCD}$ beam. EFGH. For question number 1, S-4 is only able to determine the right side of 
abcd beam. EFGH. So it can be concluded that S-4 has a slight disturbance of room relations. Furthermore, the difficulties experienced by S-4 is the difficulty in determining and using formulas to solve problem number 3 and for answer S-4 question number 3 can be seen in Figure 1 below.

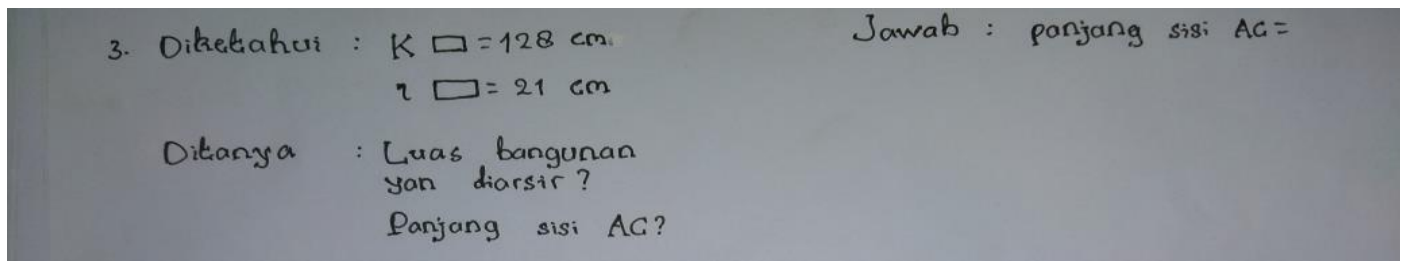

Figure 1. The Answer of S-4 Math Learning Difficulty Test at Number 3 follows:

The transcript of the researcher's interview with S-4 for question number 3 is as

Researcher: What is asked about question number 3 ?

S-4 : Calculate the area of the interpreted area and calculate the length of the ac side.

Researcher: What was the first time you did to do the problem?

S-4 : (Silent).

Researcher: Can you solve problem number 3?

S-4 : No sister.

Researcher: Try to read and look again if you can solve it?

S-4 : Emmmm does not seem sister.

Researcher: Do you have difficulty in determining and using formulas to solve the problem?

S-4: Yes sister difficult, do not understand.

Researcher: Let's see, wake up what's on the question?

S-4 : Square eh rectangular equal semicircular.

Researcher: What is the formula?

$\mathrm{S}-4$ : Do not know, if the rectangle $\mathrm{p}$ times $1 \mathrm{eh}$ it's spacious yes $\mathrm{p}$ times 1 .

From the transcript of the interview, shows that it turns out that S-4 did have difficulty in determining and using the formula of question number 3 that represents indicators of association or visual-motor impairment. Thus, it can be concluded that the S-4 undergoes a visual-motor association or combination of.

In addition, S-4 also has difficulty in recognizing and understanding symbols to solve problem number 4 . The answer to $\mathrm{S}-4$ for question number 4 is as follows (Figure 2).

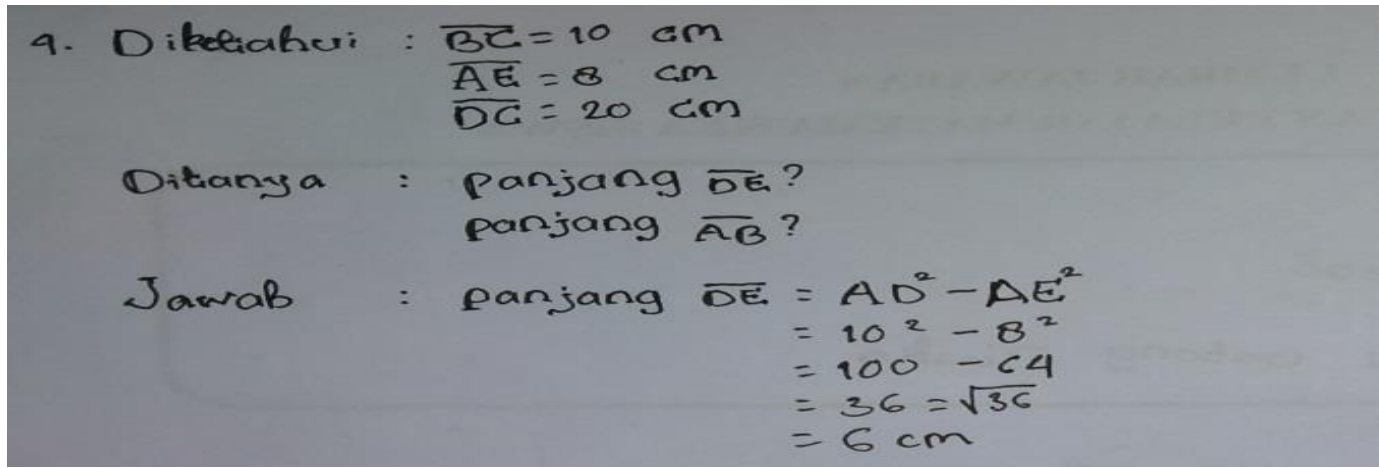

Figure 2. Answer S-4 Math Learning Difficulty Test Number 4 follows:

The transcript of the researcher's interview with S-4 for question number 4 is as Researcher: Let's read about number 4!

S-4 : On a trapezoid equal to abcd foot, $\mathrm{AB}$ length equals $\mathrm{DC}$ length and $\mathrm{AE}$ length perpendicular to $\mathrm{CD}$ length, if $\mathrm{BC}$ length is equal to $10 \mathrm{~cm}$, $\mathrm{AE}$ length is equal to $8 \mathrm{~cm}$, and $\mathrm{DC}$ length is equal to $10 \mathrm{~cm}$, what is $\mathrm{DC}$ length and $\mathrm{AB}$ length? 
Researcher: Do you know the symbols on the problem?

S-4: Which line 2 is the same as ya kak? If it's perpendicular know.

Researcher: Have you studied the symbols? S-4: Udah but forgot some.

Based on the answer sheet and the description of the interview with S-4 for question number 4 , indicates that the S-4 does not recognize the parallel line symbol. According to him, the parallel line symbol is the same symbol, but S-4 understands the symbol of the line segment and the symbol is well perpendicular. S-4 has difficulty in recognizing and understanding parallel line symbols, and has no difficulty in recognizing and understanding the long symbols of line segments and perpendicular line symbols, so that $\mathrm{S}-4$ is only able to solve some of problem number 3 . Thus, it can be said that the $\mathrm{S}-4$ has little difficulty in recognizing and understanding symbols.

Lastly, subjects with very low low mathematical connection capability (S-5) are only able to identify problem information and understand problem problems number 2 and 5 , are able to distinguish various geometric shapes and are able to determine the types of triangles related to Pythagoras theorem material, are able to understand the content of the given story, as well as carry out the settlement correctly and do not make specific miscalculations on questions number 2 and 5. However, S-4 was unable to determine the corresponding side of question number 1 , had difficulty in determining and using the formula to solve problem number 3 , and was unable to recognize and understand the symbol to solve problem number 4. Thus, S-5 does not answer questions number 1, 3, and 4 at all.

The results of this study showed that the research subjects in completing the math learning difficulty test to find out the type of math learning difficulties experienced by students when viewed from the level of mathematical connection ability produced answers with a variety of solutions. The diversity of mathematics learning difficulties of students in Pythagoras theorem material is caused by several factors, one of which is the varying level of mathematical connection ability of students.

According to the theory expressed by Cooney (1975), that students' math learning difficulties are influenced by several factors, namely physiological, social, emotional, intellectual, and pedagogical factors. One of the important sub-factors of intellectual factors that cause difficulties in learning mathematics students is the ability of mathematical connections, namely the difficulty to perform abstractions, deductions, generalizations, recalling a mathematical concept and principle. Moreover, the findings of this research corroborate those of Laili and Puspasari (2017), who found that the lower a student's level of mathematical connection ability, the more difficult it is for that student to learn mathematics.

\section{CONCLUSION}

Based on the results of data analysis and discussion of students' math learning difficulties Pythagoras theorem material is reviewed from the level of mathematical connection ability, it can be concluded that each research subject has different difficulties at each level of mathematical connection ability. Subjects with very high levels of mathematical connection ability did not experience interference with all indicators of mathematical learning difficulties. Subjects with high levels of mathematical connection ability experienced association or visual-motor response. Subjects with a level of mathematical connection capability were experiencing little association or visual-motor combination and had difficulty in recognizing and using symbols. Subjects with low levels of mathematical connection ability experienced slight disturbances of room relationships, experienced visual-motor associations or responses, and had little difficulty in recognizing and using symbols. Subjects with very low levels of mathematical connection ability experience impaired room relationships, visual-motor associations or combinations, and difficulty in recognizing and understanding symbols. Based on the results of the study, it was seen that the level of 
mathematical connection ability has a very large influence in this study, namely in determining students' math learning difficulties.

\section{RECOMMENDATION}

The results of this study are expected to be an effort to improve the quality of education in the cognitive and affective aspects of students in learning mathematics. However, there are still some limitations to this study, including: the number of research subjects is too few because the pandemic which requires the government to make regulations about the learning system in schools, so that if it is implemented in different places, subject matter, and the number of subjects, then can lead to differences in the results of the research obtained. In addition, there is a lack of time in carrying out the data collection process. So, for the next researcher in identifying problems that occur in school, it is better if they have data other than interview data, such as learning test results and observation data.

\section{ACKNOWLEDGEMENT}

The researcher would like to thank Mrs. Risnawati as the supervisor and Mr. Habibullah who gave many suggestions to researchers during the writing process of this article, so that this article can be completed properly.

\section{REFERENCES}

Azwar, S. (2016). Tes prestasi: Fungsi dan Pengembangan Pengukuran Prestasi Belajar. Yogyakarta: Pustaka Pelajar.

Cooney, T. J., Edward, D. J., \& Henderson, K. B. (1975). Dynamics of Teaching Secondary School Mathematics. Boston: Houghton Mifflin.

Hartono. (2019). Metodologi Penelitian. Pekanbaru: Zanafa Publishing.

Kumalasari, A., \& Putri, R. O. P. E. 2013). Kesulitan belajar matematika ditinjau dari segi kemampuan koneksi matematika. Prosiding Seminar Nasional Matematika dan Pendidikan Matematika FMIPA UNY.

Laili, F. J., \& Puspasari, R. (2017). Analisis kesulitan matematika siswa ditinjau dari kemampuan koneksi matematika. Jurnal Pendidikan dan Pembelajaran Matematika (JP2M), 4(1), 1-10.

Manalu, A. C. S., \& Zanthy, L. S. (2020). Analisis kesalahan siswa SMP kelas IX dalam menyelesaikan soal materi lingkaran. Jurnal Cendekia: Jurnal Pendidikan Matematika, 04(01), 104-113.

Menteri Pendidian dan Kebudayaan Republik Indonesia. (2016). Salinan Lampiran Peraturan Menteri Pendidikan dan Kebudayaan Republik Indonesia Nomor 22 Tahun 2016 Tentang Standar Proses Pendidikan Dasar dan Menengah. Jakarta: Departemen Pendidikan Nasional.

Mullis, I. V. S., Martin, M. O., Foy, P., \& Hooper, M. (2016). TIMSS 2015 International Results in Mathematics. Boston College: IEA.

Mulyani, M., \& Muhtadi, D. (2019). Peningkatan kemampuan koneksi matematis dan berpikir kreatif siswa melalui pembelajaran guided discovery di SMA Al Muttaqin. Prosiding Seminar Nasional \& Call For Papers.

NCTM. (2000). Principle and Standards for School Mathematics. Reston: The National Council of Teachers of Mathematics, Inc.

OECD. (2019). PISA 2018 Results Combined Executive Summaries Volume I, II \& III,. PISA: OECD Publisher.

Prastyo, H. (2020). Kemampuan matematika siswa Indonesia berdasarkan TIMSS. Jurnal Padegogik, 3(2), 111-117.

Qabtiyah, S. (2018). Analisis kemampuan koneksi matematis dan motivasi belajar siswa kelas VIII di SMP An-Naja Bandung Barat. Journal On Education, 1(1), 22-29. 
Rosyadi, A. A. (2018). Statistika Pendidikan. Malang: UMM Press.

Sholekah, L. M., Anggreini, D., \& Waluyo, A. (2017). Analisis kesulitan siswa dalam menyelesaikan soal matematika ditinjau dari koneksi matematis materi limit fungsi. 1(2), 151-164.

Sholihah, D. A., \& Mahmudi, A. (2015). Keefektifan experiential learning pembelajaran matematika MTs materi bangun ruang sisi datar. Wacana Akademika, 2(2), 175-185.

Siagian, M. D. (2016). Koneksi matematika dalam pelajaran matematika. MES (Journal of Mathematics Education and Science), 2(1), 58-67.

Siregar, N. R. (2016). Persepsi siswa pada pelajaran matematika: Studi pendahuluan pada siswa yang menyenangi game. Prosiding Temu Ilmiah X Ikatan Psikologi Perkembangan Indonesia.

Sugiono. (2016). Metode Penelitian Kuantitatif, Kualitatif, dan R\&D. Bandung: Alfabeta.

Trianto. (2010). Pengantar Penelitian Pendidikan Bagi Pengembangan Profesi Pendidikan dan Tenaga Kependidikan. Jakarta: Prenada Media Group.

Walle, J. A. Van de. (2007). Elementary and Middle School Mathematics: Teaching Developmentally. Boston: Pearson Education, Inc. 